Stefanie App, Janina Merk, Marion Büttgen*

\title{
Employer Branding: Sustainable HRM as a Competitive Advantage in the Market for High-Quality Employees ${ }^{* *}$
}

This conceptual article examines how Sustainable Human Resource Management (Sustainable HRM) can help establishing an attractive employer brand that can address the different needs and expectations of potential and existing employees, without compromising a consistent employer image, which can result in a sustained competitive advantage. Sustainable HRM should help firms attract and retain high-quality employees, because by integrating Sustainable HRM practices into the employee value proposition, they establish a unique, attractive employer brand. An extended employee life cycle concept depicts how the employer brand promise can be delivered to address the different needs and expectations of potential and existing employees.

Key words: sustained competitive advantage, Sustainable HRM, employer branding, employee life cycle (JEL: J20, J21, M12, M14, M51, M54)

* Stefanie App, Dipl. oec., Universität Hohenheim, Department of Marketing \& Management (570 B), Schloss Osthof-Ost, 70599 Stuttgart, Germany.

E-mail: s.app@uni-hohenheim.de.

Janina Merk, Dipl. oec., Universität Hohenheim, Department of Marketing \& Management (570 B), Schloss Osthof-Ost, 70599 Stuttgart, Germany.

E-Mail: j.merk@uni-hohenheim.de.

Marion Büttgen, Prof. Dr., Universität Hohenheim, Department of Marketing \& Management (570 B), Schloss Osthof-Ost, 70599 Stuttgart, Germany.

E-Mail: m.buettgen@uni-hohenheim.de.

** Article received: May 30, 2011

Revised version accepted after double blind review: July 23, 2012. 


\section{Introduction}

As economies become more knowledge-based, demand for highly qualified and skilled employees continues to rise, because these human resources offer a potential source of sustained competitive advantage (e.g., Moroko \& Uncles, 2008). The labor market thus is changing from a sellers' to a buyers' market (Petkovic, 2007), especially in the case of highly skilled employees, as the availability of high-value jobs is greater than the number of suitable job seekers (Grobe, 2003). In turn, human resource management (HRM) faces a challenge in attracting and retaining highly skilled, motivated employees - that is, a high-quality workforce, maintained over the long term, as a means to ensure a sustained competitive advantage for the firm (e.g., Schuler \& MacMillan, 1984; Wright \& McMahan, 1992; Wright et al., 1994; Wilkinson et al., 2001). An emphasis of Sustainable Human Resource Management (Sustainable HRM) is preserving the productivity and retention of employees so that the firm can achieve organizational goals (Ehnert, 2009a), and accordingly, a sustainability argument seems to offer a valid approach to address this challenge. The understanding of sustainability in Sustainable HRM, however, goes beyond the understanding of the term in the context of a sustained (continued) competitive advantage referring among others to aspects of resource regeneration and development (Ehnert, 2009a). Sustainable HRM also offers a possible solution for organizations that hope to promote themselves as highly responsible among potential and existing employees, in their efforts to attract and retain high-quality employees (Boudreau \& Ramstad, 2005; Jabbour \& Santos, 2008; Zaugg, 2009). To differentiate themselves from competitors in the labor market and enhance their attractiveness as employers, we suggest that organizations should establish an employer brand that includes Sustainable HRM.

However, organizations face further challenges in the competition for a highquality workforce. In particular, ageing populations, workforces from different cultural backgrounds, more women in the workplace, dual-career couples, and single parent families make it necessary to address a more diverse workforce including those at different life and career stages (Darcy et al., 2012). Therefore, we examine how the concept of Sustainable HRM might help establish an attractive employer brand that is able to address these different needs and expectations, without compromising its consistent employer image in order to achieve a sustained competitive advantage.

The concept of sustainability appears in previous corporate branding literature, such as when Hermann (2005) argues that organizations tend to integrate sustainability (primarily ecological and social aspects) into their branding and communication policies to improve their corporate reputation and attractiveness to potential employees. Corporate social performance (CSP) literature also considers whether the social aspect of Sustainable HRM can produce employer attractiveness (Turban \& Greening, 1997; Albinger \& Freeman, 2000; Greening \& Turban, 2000; Backhaus et al., 2002). Zaugg (2009) addresses the relevance of employer branding in Sustainable HRM for HRM practices in general. His exploratory findings indicate that Sustainable HRM is relevant to organizations but is not applied systematically. To extend these studies, we examine specifically how Sustainable HRM contributes to establishing a consistent employer brand that supports a sustained competitive advantage. In so doing, we es- 
tablish a conceptual framework for systematically incorporating the Sustainable HRM perspective within the employer brand.

Because Sustainable HRM in an employer branding context remains relatively unknown (Ehnert, 2009a, 2011; Zaugg, 2009; Aggerholm et al., 2011), our article contributes to this emerging area of research in several ways. First, we seek to contribute to the ongoing debate about the link between sustainability and HRM by analyzing how Sustainable HRM functions help attracting and retaining high-quality employees, which in turn can enable a sustained competitive advantage. Second, this study provides a framework for how Sustainable HRM supports the employer brand to enhance employer attractiveness. Third, it shows how integrating Sustainable HRM into the employer brand enables addressing the diverse needs and expectations of potential and existing employees in varying life and career stages.

After introducing Sustainable HRM, we discuss its role in attracting and retaining a high-quality workforce for a sustained competitive advantage. Drawing on signaling theory, social identity theory, and person-organization fit, we then link Sustainable HRM to the employer brand. Furthermore, we use an employee life cycle (ELC) concept to show how Sustainable HRM might contribute to a consistent employer brand that promises to address different needs and expectations of employees in various phases of their ELC. Finally, we draw conclusions and note implications for research and practice.

\section{Sustainable HRM as a source of sustained competitive advantage}

In Strategic HRM literature, attention centers on the resource-based view of the firm as a means to explain how people (human resources), as well as HRM practices, can provide a sustained competitive advantage (e.g., Wright \& McMahan, 1992; Wright et al., 1994). Organizations achieve a sustained competitive advantage by implementing value-enhancing strategies that differentiate them from their competitors and are difficult for competitors to duplicate (Barney, 1991). The resource-based view asserts that an organization's competitive advantage and thus its success depends on its supply and effective use of resources. If resources are valuable, rare, non-substitutable, and inimitable, they are considered as important and strategic and enable the organization to gain a sustained competitive advantage (Barney, 1991). Wright and McMahan (1992) thus argue that human resources have the potential to be sources of sustained competitive advantage, though they also note that to do so, the employees must be both highly skilled and motivated-that is, a high-quality workforce.

Other research offers evidence that HRM can contribute to a sustained competitive advantage by establishing suitable HRM practices to create and develop a highquality workforce (e.g., Lado \& Wilson, 1994; Wright et al., 1994; Huselid, 1995; Delery \& Doty, 1996; Huselid et al., 1997). Although Wright et al. (1994) posit that most HRM practices can be imitated and/or substituted, such that they might not be a source of sustained competitive advantage, Lado and Wilson (1994) refute this claim and assert instead that it is difficult to imitate HRM practices. Because they often are firm specific and reflect the organization's particular circumstances, HRM practices are not easily transferable from one organization to another. This view seems well established in current Strategic HRM literature (e.g., Wright et al., 2001). Consequently, 
human resources and their management by organizations likely are important sources of competitive advantage, and it becomes crucial to identify ways to attract, develop, and retain high-quality employees.

\section{Defining sustainability in an HRM context}

Sustainability is increasingly important for management research and practice (e.g., Elkington, 1997; Müller-Christ, 2001; Dyllick \& Hockerts, 2002; Ehnert, 2009a, 2009b), yet its link to HRM is just beginning to receive attention (e.g., Wilkinson et al., 2001; Zaugg et al., 2001; Thom \& Zaugg, 2004; Boudreau \& Ramstad, 2005; Jabbour \& Santos, 2008; Zaugg, 2009; Ehnert, 2009a, 2009b, 2010, 2011; Clarke, 2011b; SHRM, 2011). The scarcity of high-quality employees and increasing strains on employees (e.g., performance and time pressures, stress levels, work-life imbalances) have refocused attention on the HRM strategies organizations use to manage their potential and existing employees in the long term to secure organizational survival (Ehnert, 2009a, 2009b, 2011; Wilkinson et al., 2001).

According to Ehnert (2009a, p. 74), "Sustainable HRM is the pattern of planned or emerging human resource strategies and practices intended to enable organizational goal achievement while simultaneously reproducing the HR base over a long-lasting calendar time." That is, Sustainable HRM, among other factors, focuses on preserving the productivity and retention of an organization's human resource base to achieve economic efficiency and effectiveness and ensure long-term viability (Ehnert, 2009a, 2010). Thus it extends the focus of Strategic HRM, beyond increasing economic efficiency and effectiveness and contributing to financial success through planned HRM activities (Wright \& McMahan, 1992). Ehnert (2009a) stresses both the economic rationale and social responsibility, again moving beyond the focus of Strategic HRM and in alignment with our understanding of Sustainable HRM. We therefore consider how organizations create value for potential and existing employees by investing in the long-term availability and viability of employees, which ensures a high-quality workforce for the future. Müller-Christ and Remer (1999) refer to this as the 'substanceoriented' understanding which considers the social as well as the economic rationale of sustainability. This understanding derives from an economic understanding of sustainability by Aristotle and old European forestry laws. Transferred to the HRM context, substance orientation involves a balance between the consumption and the 'reproduction' (i.e., regeneration, development) of human resources, while also emphasizing an organization's need to invest in the 'origin' of human resources (e.g., universities, education systems, labor markets, families) to secure a long-term supply and organizational survival (Ehnert, 2009a, 2009b, 2010).

Because Sustainable HRM should exert a positive influence on how organizations treat their employees, we posit that the concept also may influence the organization's attractiveness as an employer, such that Sustainable HRM has the potential to provide a sustained competitive advantage.

\section{Increasing employer attractiveness through Sustainable HRM}

Cable and Turban (2003) find that potential employees' positive perceptions of an organization's reputation influence their desire to pursue employment with the organiza- 
tion. Reputation refers to public evaluations of an organization, relative to other organizations (Fombrum \& Shanley, 1990). Turban and Cable (2003) show that organizations with better reputations attract a larger pool of job seekers and then can select employees from an applicant pool that includes more high-quality employees.

Support for our prediction that Sustainable HRM positively influences employer attractiveness also appears in corporate social performance (CSP) and corporate social responsibility (CSR) literature. The social dimension of sustainability is sometimes used synonymously with CSP, CSR, or corporate ethics (Ehnert, 2009a, 2009b), and the overlaps among these concepts suggest that the results of prior studies serve as a good basis for further theoretical developments. However, some essential differences also must be considered (Jones Christensen et al., 2007). Corporate ethics focuses on moral aspects in a business context (Ehnert, 2009a); CSR pertains to an organization's voluntary social and environmental activities in its business operations and in interactions with stakeholders; CSP refers to an evaluation to determine if organizations are meeting their CSR (Turban \& Greening, 1997; Albinger \& Freeman, 2000; Greening $\&$ Turban, 2000). None of these aspects covers a substance-oriented understanding of Sustainable HRM though. That is, potential and existing employees actually perceive the HRM of an organization as sustainable, through a substance-oriented understanding.

A few studies note a positive association between CSP and employer attractiveness; for example, Turban and Greening (1997) indicate that published ratings of an organization's CSP enhance its corporate reputation and attractiveness as an employer, and Greening and Turban (2000) show that applicants are more likely to seek employment with socially responsible organizations. Albinger and Freeman (2000) investigate the effects of CSP for different job-seeking populations and show that CSP relates positively to employer attractiveness among applicants with more job choices. In the context of Sustainable HRM, an organization's pertinent strategy could attract and retain high-quality employees, establishing a sustained competitive advantage. Accordingly, we suggest:

Proposition 1: Sustainable HRM positively affects employer attractiveness.

\section{Linking Sustainable HRM to the employer brand}

Our first proposition suggests that organizations should use Sustainable HRM to position themselves as attractive employers in the labor market and achieve employer of choice status. To position an organization as an attractive employer, the concept of employer branding has been established (Ambler \& Barrow, 1996; Backhaus \& Tikoo, 2004; Barrow \& Mosley, 2005; Lievens et al. 2007). The initial discussion of the employer brand by Ambler and Barrow (1996, p. 187) included the following definition: "the package of functional, economic, and psychological benefits provided by employment, and identified with the employing company." Thus an employer brand contains multiple facets, all of which should express what the organization, as an employer, represents. Through these facets, the organization aims to achieve status as an employer of choice (Backhaus \& Tikoo, 2004). However, employer branding remains a relatively new, little-researched field. Existing research mainly concentrates on build- 
ing conceptual frameworks and explaining how to increase employer attractiveness (e.g., Berthon et al., 2005; Moroko \& Uncles, 2008).

Furthermore, in existing literature, an employer brand often relates closely to the corporate brand (e.g., Mosley, 2007; Foster et al., 2010), which is based on the organizational culture and values. The corporate brand determines an organization's identity and should create a distinctive image (Keller, 1993), which is the sum of perceived positive and negative associations formed by an individual's perception of the organization (Dowling, 1986). Whereas the corporate brand addresses all stakeholders, the employer brand primarily addresses (potential and existing) employees; in this sense, it is a sub-brand of the corporate brand (Foster et al., 2010). By establishing an employer brand, organizations aim to provide a unique employment offering that positively differentiates them from competitors. If they can create an image as a great place to work, they likely can attract and retain a skilled and motivated workforce (Ambler \& Barrow, 1996; Moroko \& Uncles, 2008).

Building a brand for employees can also increase organizational success, because it has the potential to minimize costs (e.g., in recruiting and income development) through more efficient and effective communication (Knox \& Freeman, 2006). In addition, Cable and Turban (2003) show that potential employees are willing to accept a lower salary to pursue employment with an organization which has a positive reputation.

Finally, the organization's employer brand image reflects the perceptions of existing and potential employees, so an employee perspective must be adopted to effectively position an employer brand. As argued previously, a substance-oriented understanding of Sustainable HRM indicates that organizations themselves should secure the long-term supply and 'reproduction' of their human resources and not rely on supply from labor markets. From an employee's perspective, this securing involves investments in the human resource base, to create value for existing and potential employees, and therefore enhances the organization's attractiveness as an employer. Including Sustainable HRM in the employer brand thus might be a promising route to employer attractiveness. Sustainable HRM also enhances the organization's ability to attract and retain high-quality employees, leading to a sustained competitive advantage. Several theories support our recommendation to integrate Sustainable HRM into the employer brand.

\section{Signaling theory}

All organizational activities are perceived as signals sent by the organization. During job-seeking processes, potential employees need the organization to signal its characteristics as an employer, to bridge asymmetries in information (i.e., the potential employer knows more than the potential employee). The potential employees can use this information to form their opinions about what it would be like to work for that organization (Greening \& Turban, 2000; Celani \& Singh, 2011).

According to signaling theory, integrating Sustainable HRM into the employer brand thus might be a promising approach to position the employer in the labor market and enhance employer attractiveness. By communicating Sustainable HRM, the firm enables potential employees to interpret the signal of a substance-oriented under- 
standing of the employment relationship. In turn, more high-quality employees are likely to perceive the firm as a great place to work. Therefore, we propose that integrating Sustainable HRM into the employer brand leads to sustained competitive advantage:

Proposition 2: Integrating Sustainable HRM within the employer brand sends a positive signal of a substance-oriented understanding of the employment relationship.

\section{Social identity theory}

Social identity theory indicates that a person's self-concept depends on their membership in different social organizations (Ashforth \& Mael, 1989). An employee's selfconcept is strongly influenced by the image and reputation of the employing organization (Greening \& Turban, 2000). Employees can enhance their self-concept by comparing their organization against other, less favorable organizations. Therefore, an organization's positive image and reputation contribute to individual self-concepts (Ashforth \& Mael, 1989; Mael \& Ashforth, 1992; Backhaus \& Tikoo, 2004; Lievens et al., 2007).

In particular, employees can use the employer brand to compare organizations, in which case the employer brand affects their self-concepts. Because Sustainable HRM should add value for employees and thus contribute to the individual self-concept, organizations should integrate Sustainable HRM into their employer brand. Such an integration also should enable organizations to positively differentiate themselves from competitors, which further enhances an employee's self-concept. High-quality employees should be attracted to and retained by the firm, which means that integrating Sustainable HRM into the employer brand can lead to a sustained competitive advantage. These arguments lead to our next proposition:

Proposition 3: Integrating Sustainable HRM in the employer brand enhances the self-concept of existing and potential employees.

\section{Person-organization fit}

Person-organization fit might help explain the effect of Sustainable HRM within the employer brand; it proposes that job seekers match their personal characteristics and values with the organization's culture and identity to achieve congruence or a best possible fit (Cable \& Judge, 1996 Cable \& DeRue, 2002). If an individual perceives fit with the organization, they are more likely to pursue employment there.

We assume that employees are interested in preserving their personal resources (such as their employability or health) and therefore prefer to be treated according to a substance-oriented understanding of Sustainable HRM. Integrating Sustainable HRM might enable organizations to achieve congruence for both potential and existing employees with the organization. Furthermore, CSP literature suggests that personorganization fit is particularly pertinent for high-quality employees, because they tend to value these less material benefits (Albinger \& Freeman, 2000). The overlaps between CSP and Sustainable HRM suggest similar effects in our setting, namely, that in- 
tegrating Sustainable HRM into the employer brand can lead to a sustained competitive advantage. Therefore, we assume:

Proposition 4: The perceived fit between potential and existing employees' values and Sustainable HRM moderates the relationship between Sustainable HRM and employer attractiveness; such as higher is the fit, stronger will be the positive impact of Sustainable HRM on employer attractiveness.

\section{Integrating Sustainable HRM practices in the EVP}

As we have argued, Sustainable HRM should contribute to the employer brand and enhance employer attractiveness. The next step is to investigate how to integrate Sustainable HRM within the employer brand. Drawing on marketing principles, we posit that the employer brand should be known and noticeable, relevant and resonant, and unique (Moroko \& Uncles, 2008; Foster et al., 2010). Similar to a unique selling proposition in the consumer market, the set of provided benefits should ensure a good employee value proposition (EVP) (Barrow \& Mosley, 2005).

According to its definition, an employer brand provides several benefits (Ambler \& Barrow, 1996; Lievens \& Highhouse, 2003; Lievens et al., 2007; Mosley, 2007). On the one hand, potential and existing employees seek instrumental (i.e., functional/economical) benefits, so they evaluate objective and factual employment attributes (e.g., salary). On the other hand, they need symbolic (i.e., subjective/psychological) benefits, which refer to the intangible attributes that people assign to an employer (e.g., job satisfaction, reputation) (Lievens \& Highhouse, 2003). Lievens et al. (2007) discuss the relationships of applicant attraction, instrumental benefits, and symbolic image dimensions. With this distinction, they argue that instrumental employment attributes are increasingly similar, so organizations additionally must provide symbolic employment attributes to differentiate themselves from competitors in the labor market. The possibility of comparing different employment offers reinforces the need for organizations to create greater appeal as an employer (Lievens \& Highhouse, 2003).

Several employment attributes must be included when establishing an employer brand. Drawing on a basic definition of the employer brand, the EVP should contain functional, economical, and psychological benefits (Ambler \& Barrow, 1996). It might provide these benefits through HRM practices, which establish positive perceptions of the employment relationship and serve to attract, retain, motivate, develop, and productively use human resources in an organization (Huselid, 1995; Chan et al., 2004). HRM can design the EVP by developing adequate practices that support differentiation from competitors. Accordingly, it is important to identify which HRM practices an organization needs to establish to gain its sustained competitive advantage.

We suggest, that to ensure a competitive workforce and a permanent supply of quality human resources, the EVP should contain Sustainable HRM practices. In alignment with a substance-oriented understanding of Sustainable HRM, such practices (e.g., work-life balance, employability, worksite health care programs) seek to balance the consumption and 'reproduction' of human resources and invest in their origin. The organization can secure the availability and viability of employees over the long-term and achieve a sustained competitive advantage. 
Many organizations already have realized the advantages of such HRM practices (Ehnert, 2009a, 2009b), according to the increased attention to topics such as employer branding, employability, work-life balance, and demographic changes (Ehnert, 2010). Research institutes explicitly aim to help organizations enhance their recruiting activities by identifying relevant aspects of employer attractiveness (Grobe, 2003). In these studies, training and development, self-responsibility, and work-life balance are critical to job choices (e.g., Grobe, 2003; Trendence, 2012). These aspects also align with our understanding of Sustainable HRM practices, because they reflect a substance-oriented understanding. Therefore, Sustainable HRM practices may enhance employer attractiveness in the view of high-quality workers.

Yet Sustainable HRM has not been systematically integrated into organizations (Zaugg et al., 2001; Thom \& Zaugg, 2004). Most organizations have a long way to go to catch up with Sustainable HRM practices and those firms that are more active in this field enjoy greater profitability and a higher degree of competitiveness in the labor market (Zaugg, 2009). Therefore, Sustainable HRM practices have the potential to strengthen the attractiveness of an employer brand, and we propose:

Proposition 5: An EVP containing Sustainable HRM practices positively affects an organization's employer brand.

\section{Addressing different needs and expectations in different stages through the EVP}

A consistent EVP must persist for the whole period of employment: Employees decide to start and then continue their employment relationship, such that they can contribute to the organization's durable supply of high-quality human resources. Through the EVP, an organization makes a promise that creates beliefs and expectations among employees. These promises and resulting beliefs if realized and maintained establish a perceptual, reciprocal contract between employer and employee, that is, the psychological contract (Rousseau, 1995; Robinson, 1996). A psychological contract exists in addition to the legal employment agreement and is based on implicit or explicit promises (Rousseau, 1995; Robinson, 1996). If the employer does not keep its promises (as provided by the employer brand), a revision or breach of the psychological contract can occur. In the worst case, it leads to the employee's withdrawal from the organization and a potential loss of the sustained competitive advantage (Rousseau, 2001). Accuracy and consistency in internal and external communication are required to deliver a consistent employer image (Moroko \& Uncles, 2008).

However, if organizations aim to establish an employer brand that creates value for their potential and existing employees, they also need to provide a consistent brand proposition and guarantee enough flexibility to appeal to many types of employees (Barrow \& Mosley, 2005). Organizations must address a diverse workforce (e.g., older employees, workers from different cultural backgrounds, more women in the workforce) with different needs and expectations of employment. These needs and expectations also might change over different life and career stages. For example, a single mother with children, dual-career couples, and single-earner men follow different life and career paths and express individual needs, which produce different ex- 
pectations (e.g., career advancement, work-life balance) throughout their employment period (Cooke, 1994; Robinson, 1996; Lievens et al., 2007). As needs and expectations change over time, the psychological contract is continually renegotiated (Rousseau, 2001). This evolving process should be considered when establishing an employer brand, which underlines the need to deliver a consistent, holistic (but flexible) EVP.

We argue that Sustainable HRM practices have the potential to address such differing needs and expectations and thereby help the employer brand address both potential and existing employees in their various life and career stages. To consider how Sustainable HRM practices might attract and retain potential and existing employees in different life and career stages and establish a consistent employer brand, we use the employee life cycle (ELC) concept.

The ELC is an HRM development concept that aligns HRM activities with different life and career stages to increase and maintain the employee's performance over time (Graf, 2002; Zaugg, 2009). According to the ELC, four phases describe the ideal development of an employee with increasing age and work experience: introduction phase, growth phase, maturity phase, and decline phase (Graf, 2002). The duration of each phase depends on each employee's characteristics but also can be influenced by HRM practices (Schein, 1978). Because the employer brand signals to potential and existing employees, we propose extending the four phases to include pre-employment and post-employment phases, which aligns with a substance-oriented understanding of Sustainable HRM. We next discuss how the employer brand should address different phases through Sustainable HRM.

\section{Pre-employment phase}

In the pre-employment phase, an organization aims to attract potential employees who are not yet familiar with the organization's values and norms and use the employer brand to evaluate what it would be like to work for the organization. The challenge is to communicate the attractions of the employer brand, or specifically its EVP, to attract a high-quality workforce. The organization should send positive signals about working conditions (Moroko \& Uncles, 2008). Sustainable HRM practices should be noticeable to potential employees and influence their perceptions of the employer. Therefore, we recommend that an organization should promote its substance-oriented understanding of the employment relationship (e.g., which HR activities foster employee regeneration and development). Because a potential employee's beliefs and expectations are formed before they join the organization (Rousseau, 2001), it is essential to send accurate and consistent signals to these potential employees (Moroko \& Uncles, 2008).

The substance-oriented understanding of Sustainable HRM also suggests that it is important to invest in the 'origin' of the human resource base of the firm. Organizations should establish education systems, cooperate with schools and universities, or even launch their own corporate universities or schools (Ehnert, 2010). This approach helps engage potential employees and ensure the availability and viability of highquality human resources. In turn, the firm should gain an image as a substanceoriented employer. Among a student target group, Turban (2001) confirms that information about an organization, provided through social interactions (such as on- 
campus activities), influences organizational attractiveness. Organizations should undertake such activities and/or host internships to strengthen their image. Even if the student ultimately decides not to work for the organization, they are likely to become an important ambassador for the firm and might encourage other potential employees (Moroko \& Uncles, 2008). This investment thereby helps assure the long-term availability of qualified human resources.

\section{Introduction phase}

In the introduction phase, an employee starts working for an organization but has not yet acquired the necessary organization-specific knowledge and skills. By working for the organization, employees receive additional information and a realistic impression of the employer (Rousseau, 2001). As the employee compares pre-employment expectations with actual employment conditions, it is critical that the received signals not contradict the signals received in the pre-employment phase, to avoid the risk of a psychological contract breach (Rousseau, 2001; Graf, 2002). Again, accurate and consistent, internal and external communication of Sustainable HRM practices through the EVP is critical.

As a member of the organization, the employee's attitude and behavior influence perceived external reputation. Integrating and socializing the employee is the purpose of this phase (Schein, 1978; Graf, 2002). The organization must motivate the employee to live the brand, which can happen only if the employee perceives the employer brand as attractive (Maxwell \& Knox, 2009). We argue that such attractiveness is encouraged by integrating Sustainable HRM within the employer brand.

Cable and Parsons (2001) also assert that socialization tactics influence turnover, organizational commitment, and whether the employee internalizes and lives the organization's values and norms. Therefore, an organization should carefully manage the socialization processes (Foster et al., 2010) by inculcating a substance-oriented understanding of Sustainable HRM into employees' minds. A mentoring program for new employees might help them identify quickly with the organization, internalize the substance-oriented understanding, and live the employer brand, for example. Mentoring also addresses Sustainable HRM by enabling higher productivity of newcomers, who quickly become familiar with the organization and thus more readily can achieve higher performance. Mentoring also potentially invigorates the workforce, as newcomers learn from experienced employees.

\section{Growth phase}

In the third, growth phase, employees accelerate their performance through learning and continue to develop professionally and personally. They form individual careers (Graf, 2002). Thus, the employer brand should concentrate on tapping their potential and encourage career development through Sustainable HRM practices. This effort represents another investment in the value of the workforce.

As an example, women traditionally have been more likely to experience disruptions to their career because of the greater challenges they face in balancing family responsibilities with their professional career. To support their careers and the supply of high-quality female workers in the workforce, organizations might, within equal op- 
portunities regulations, introduce women-only development programs and identify successful role models and mentors (Clarke, 2011a).

\section{Maturity phase}

In the maturity phase, employees might reach a point where their career is stagnating, and they are at risk of reaching a career plateau. In the worst case, this might prompt withdrawal from the organization, putting organizations at risk of losing a good source of sustained competitive advantage and high-quality employees (Graf, 2002), who are highly prized recruits to competitors. To remain the employer of choice, the firm should use Sustainable HRM practices to emphasize employee retention and focus on maintaining and enhancing performance, employee health and well-being.

High-quality employees often exceed their maximum stress level and risk 'burnout', especially if time for regeneration is neglected (Brödner, 2009). To avoid the threat of declining performance, organizations should establish work-life balance or onsite health care programs (e.g., Bertera, 1990; Konrad \& Mangel, 2000; Dejoy et al., 2010), which can help preserve the productivity and retention of an organization's human resources.

\section{Decline phase}

In this phase, performance suffers (Graf, 2002). From a Sustainable HRM perspective, it is important to identify the reasons for declining performance and initiate proper countermeasures or recovery means. Employees should not be overstrained, so one possible approach is to find an alternative position, within the organization, that better matches their new situation.

The ELC typically ends with an employee's withdrawal from the organization. Regardless of whether it is due to a breach of the psychological contract, a natural cause (e.g., retirement), or redundancy due to downsizing, organizations should continue to signal that they value the employment relationship, to maintain their status as a great place to work. If downsizing occurs, organizations that have invested in the employability of their human resources more likely mitigate negative effects on their employer brand, because the released employees have better chances of finding new jobs (Thom \& Schüpbach-Brönnimann, 2003; Ehnert, 2009a).

\section{Post-employment phase}

Because former employees still have the potential to influence an employer's reputation, we argue that another phase has to be considered within the employer brand. In the post-employment phase, former employees serve as ambassadors of the organization, who provide a realistic employment preview and positively influence potential and existing employees (Moroko \& Uncles, 2008). This influence then improves the employer brand by promoting the organization as a great place to work, which aligns with Sustainable HRM in the sense that it expands the human resource base. Therefore, firms should encourage their former employees to help them attract potential employees. They might establish a post-employment pool to stay in touch with former employees; if the pool includes employees who had to leave due to downsizing, the organization can easily contact them if it regains the capacity to hire employees. 
Figure 1: Sustainable HRM as a key consideration of the employer brand in every phase of the ELC
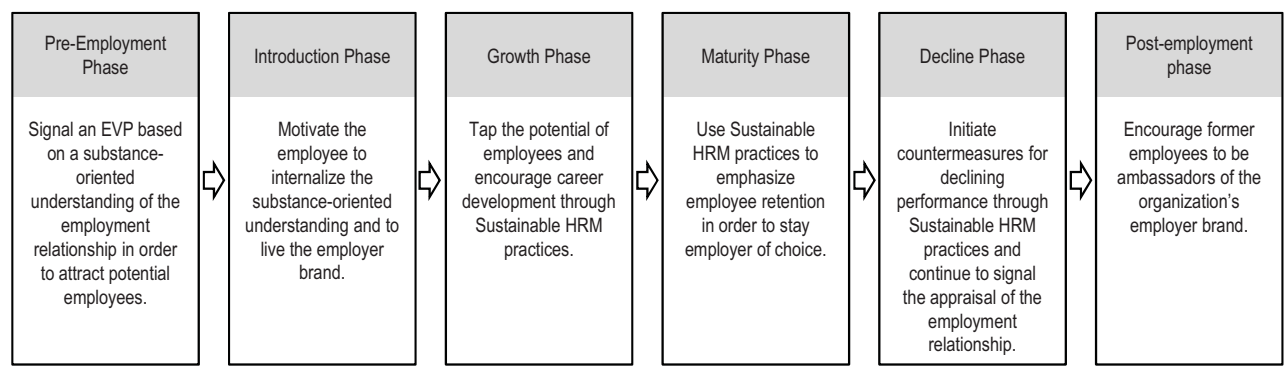

In summary, a consistent employer brand demands a substance-oriented understanding of Sustainable HRM that remains a key consideration in every phase of the ELC (fig. 1), so that employees perceive the employment relationship as sustainable. These arguments lead to the following proposition:

Proposition 6: An EVP containing Sustainable HRM practices enables an organization to address the diverse needs and expectations of existing and potential employees in different life and career stages.

\section{Conclusion}

We have attempted to demonstrate how integrating Sustainable HRM into the employer brand can lead to a sustained competitive advantage. Adding to the conversation about the scarcity of highly qualified and motivated employees, we provide a conceptual basis for linking Sustainable HRM to employer branding as a means to attract and retain a high-quality workforce. For this contribution, we have adapted research on CSP (Turban \& Greening, 1997; Albinger \& Freeman, 2000; Greening \& Turban, 2000; Backhaus et al., 2002) to suggest that organizations implementing Sustainable HRM can increase their employer attractiveness and thereby enhance their ability to attract and retain high-quality employees, leading to a competitive advantage. By establishing an effective employer brand, organizations increase their attractiveness and even earn the status as an employer of choice (Moroko \& Uncles, 2008). We suggest that organizations that establish an employer brand based on Sustainable HRM thus gain an important tool for attracting and retaining high-quality employees. The EVP, which delivers the employer brand promise, should contain Sustainable HRM practices, because these promote a substance-oriented employer image. Organizations can then differentiate themselves from competitors in the labor market.

To link Sustainable HRM to the employer brand, we turn to existing theory. For example, signaling theory implies that the employer brand can signal the advantages of its employment offer. In addition, social identity theory suggests that a positive image as a substance-oriented employer might enhance potential and existing employees' self-concepts, which makes the employer more attractive. Furthermore, perceived fit between personal characteristics and the EVP provided by the organization can improve the organization's attractiveness as an employer. 
Because organizations face challenges in addressing a diverse workforce, various needs and expectations should be considered when establishing the employer brand. Personal characteristics or expectations also can change over time, such that the psychological contract is continuously renegotiated. We suggest that integrating Sustainable HRM practices in the EVP enables organizations to address existing and potential employees in different life and career stages. Using the ELC concept, we build a framework of ways to address existing and potential employees in different life and career stages through Sustainable HRM practices. To ensure that both potential and existing employees are included, we propose extending the original four stages of the ELC concept to include pre-employment and post-employment phases. The emphasis of an employer brand is mainly on attracting potential employees in the first phase, then remaining attractive for existing employees and retaining them in the other phases including retaining goodwill in the post-employment phase. In each phase, we have presented examples of different practices that align with Sustainable HRM. By integrating Sustainable HRM practices within its employer brand, an organization can address the different needs and expectations of its workforce without compromising its consistent employer image.

The ELC cannot capture all the complexity of managing HR before, during, and after employment. However, the implications we have presented serve as a useful framework for approaching potential, existing and former employees in different life and career stages through Sustainable HRM integrated into the employer brand. Further research also should investigate which Sustainable HRM practices are most promising for increasing employer attractiveness in each phase. A longitudinal study could investigate how the needs and expectations of potential and existing employees change with regard to employer attractiveness throughout the ELC. Future research should also investigate which Sustainable HRM practices (e.g., work-life balance, employability) have the strongest impact on employer brand-related outcomes. Because employees develop relationships with the organization and with their immediate supervisors (Wayne et al., 1997), it also would be interesting to investigate the impact that superiors have on substance-orientation perceptions.

In summary, this article provides an initial conceptualization of how Sustainable HRM can contribute to positioning the employer brand. Although there has been little attempt to bridge Sustainable HRM research and employer attractiveness, additional studies are necessary to empirically test the impact of Sustainable HRM on the employer brand.

\section{References}

Aggerholm, H.K., Andersen, S.E., \& Thomsen, C. (2011). Conceptualising employer branding in sustainable organisations. Corporate Communications: An International Journal, 16(2), 105-123.

Albinger, H.S., \& Freeman, S.J. (2000). Corporate social performance and attractiveness as an employer to different job seeking populations. Journal of Business Ethics, 28(3), 243-253.

Ambler, T., \& Barrow, S. (1996). The employer brand. Journal of Brand Management, 4(3), 185-206.

Ashforth, B.E., \& Mael, F. (1989). Social identity theory and the organization. Academy of Management Review, 14(1), 20-39.

Backhaus, K.B., Stone, B.A., \& Heiner, K. (2002). Exploring the relationship between corporate social performance and employer attractiveness. Business Society, 41(3), 292-318. 
Backhaus, K., \& Tikoo, S. (2004). Conceptualizing and researching employer branding. Career Development International, 9(5), 501-517.

Barney, J. (1991). Firm resources and sustained competitive advantage. Journal of Management, 17(1), 99120.

Barrow, S., \& Mosley, R. (2005). The employer brand. Bringing the best of brand management to people at work. London: Wiley \& Sons Ltd.

Bertera, R.L. (1990). The effects of workplace health promotion on absenteeism and employment costs in a large industrial population. American Journal of Public Health, 80(9), 1101-1105.

Berthon, P., Ewing, M., \& Hah, L.L. (2005). Captivating company: Dimensions of attractiveness in employer branding. International Journal of Advertising, 24(2), 151-172.

Boudreau, J.W., \& Ramstad, P.M. (2005). Talentship, talent segmentation, and sustainability: A new HR decision science paradigm for a new strategy definition. Human Resource Management, 44(2), 129-136.

Brödner, P. (2009). Sustainability in knowledge-based companies. In P. Docherty, M. Kira, \& A.B. Shani (eds.), Creating sustainable work systems: Developing social sustainability (2nd ed., pp. 53-69). London: Routledge.

Cable, D.M., \& DeRue, D.S. (2002). The convergent and discriminant validity of subjective fit perceptions. Journal of Applied Psychology, 87(5), 875-884.

Cable, D.M., \& Judge, T.A. (1996). Person-organization fit, job choice decisions, and organizational entry. Organizational Behavior and Human Decision Processes, 67(3), 294-311.

Cable, D.M., \& Parsons, C.K. (2001). Socialization tactics and person-organization fit. Personnel Psychology, 54 (1), 1-23.

Cable, D.M., \& Turban, D.B. (2003). The value of organizational reputation in the recruitment context: A brand-equity perspective. Journal of Applied Psychology, 33(11), 2244-2266.

Celani, A., \& Singh, P. (2011). Signaling theory and applicant attraction outcomes. Personnel Review, 40(2), 222-238.

Chan, L.L.M., Shaffer, M.A., \& Snape, E. (2004). In search of sustained competitive advantage: The impact of organizational culture, competitive strategy and human resource management practices on firm performance. International Journal of Human Resource Management, 15(1), 17-35.

Clarke, M. (2011a). Advancing women's careers through leadership development programs. Employee Relations, 33(5), 498-515.

Clarke, M. (2011b). Readings in HRM and sustainability. Prahran: Tilde University Press.

Cooke, D.K. (1994). Measuring career stage. Human Resource Management Review, 4(4), 383-398.

Darcy, C., McCarthy, A., Hill, J., \& Grady, G. (2012). Work-life balance: One size fits all? An exploratory analysis of the differential effects of career stage. European Management Journal, 30(2), 111-120.

DeJoy, D.M., Wilson, M.G., Vandenberg, R.J., McGrath-Higgins, A.L., \& Griffin-Blake, C.S. (2010). Assessing the impact of healthy work organization intervention. Journal of Occupational and Organizational Psychology, 83(1), 139-165.

Delery, J.E., \& Doty, D.H. (1996). Modes of theorizing in strategic human resource management: Tests of universalistic, contingency, and configurational performance predictions. Academy of Management Journal, 39(4), 802-835.

Dowling, G.R. (1986). Managing your corporate images. Industrial Marketing Management, 15(2), 109-115.

Dyllick, T., \& Hockerts, K. (2002). Beyond the business case for corporate sustainability. Business Strategy and the Environment, 11(2), 130-141.

Ehnert, I. (2009a). Sustainable buman resource management: A conceptual and exploratory analysis from a paradox perspective. Heidelberg: Physica-Verlag.

Ehnert, I. (2009b). Sustainability and human resource management: Reasoning and applications on corporate websites. European Journal of International Management, 3(4), 419-438.

Ehnert, I. (2010). Nachhaltigkeit im HR-Management. Spannungen aushalten, Widersprüche bewältigen. Personalfübrung, 43(5), 26-36.

Ehnert, I. (2011). Sustainability and human resource management. In A. Wilkinson, \& K. Townsend (eds.), The future of employment relations (pp. 215-237). Hampshire: Palgrave MacMillan. 
Elkington, J. (1997). Cannibals with forks: The triple bottom line of 21st century business. Oxford: Capstone.

Fombrun, C., \& Shanley, M. (1990). What's in a name? Reputation building and corporate strategy. Academy of Management Journal, 33(2), 233-258.

Foster, C., Punjaisri, K., \& Cheng, R. (2010). Exploring the relationship between corporate, internal and employer branding. Journal of Product \& Brand Management, 19(6), 401-409

Graf, A. (2002). Lebensayklusorientierte Personalentwicklung. Ein Ansatz für die Erhaltung und Förderung von Leistungsfähigkeit und -bereitschaft wäbrend des gesamten betrieblichen Lebensayklus. Bern: Haupt.

Greening, D.W., \& Turban, D.B. (2000). Corporate social performance as a competitive advantage in attracting a quality workforce. Business \& Society, 39(3), 254-280.

Grobe, E. (2003). Corporate Attractiveness-eine Analyse der Wabrnebmung von Unternebmensmarken aus der Sicht von High Potentials. (HHL Arbeitspapier Nr. 50). Leipzig.

Hermann, S. (2005). Corporate Sustainability Branding. Nachbaltigkeits- und stakeholderorientierte Profilierung von Unternehmensmarken. Wiesbaden: DUV.

Huselid, M.A. (1995). The impact of human resource management practices on turnover, productivity, and corporate financial performance. Academy of Management Journal, 38(3), 635-672.

Huselid, M.A., Jackson, S.E., \& Schuler, R.S. (1997). Technical and strategic human resource management effectiveness as determinants of firm performance. Academy of Management Journal, 46(1), 171188.

Jabbour, C.J.C., \& Santos, F.C.A. (2008). The central role of human resource management in the search for sustainable organizations. International Journal of Human Resource Management, 19(12), 2133-2154.

Jones Christensen, L., Peirce, E., Hartman, L.P, Hoffmann, W.M., \& Carrier, J. (2007). Ethics, CSR, and sustainability education the Financial Times Top 50 global business schools: Baseline data and future research directions. Journal of Business Ethics, 73(4), 347-368.

Keller, K.L. (1993). Conceptualizing, measuring, and managing customer-based brand equity. Journal of Marketing, 57(1), 1-22.

Knox, S., \& Freeman, C. (2006). Measuring and managing employer brand image in the service industry. Journal of Marketing Management, 22(7-8), 695-716.

Konrad, A.M., \& Mangel, R. (2000). The impact of work-life programs on firm productivity. Strategic Journal of Management, 21(12), 1225-1237.

Lado, A.A., \& Wilson, M.C. (1994). Human resource systems and sustained competitive advantage: A competency-based perspective. Academy of Management Review, 19(4), 699-727.

Lievens, F., \& Highhouse, S. (2003). The relation of instrumental and symbolic attributes to a company's attractiveness as an employer. Personnel Psychology, 56(1), 75-102.

Lievens, F., Van Hoye, G., \& Anseel, F. (2007). Organizational identity and employer image: Towards a unifying framework. British Journal of Management, 18(1), S45-S59.

Mael, F., \& Ashforth, B.E. (1992). Alumni and their alma mater: A partial test of the reformulated model of organizational identification. Journal of Organizational Behavior, 13(2), 103-123.

Maxwell, R., \& Knox, S. (2009). Motivating employees to "live the brand": A comparative case study of employer brand attractiveness within the firm. Journal of Marketing Management, 25(9), 893-907.

Moroko, L., \& Uncles, M.D. (2008). Characteristics of successful employer brands. Journal of Brand Management, 16(3), 160-175.

Mosley, R.W. (2007). Customer experience, organizational culture and the employer brand. Journal of Brand Management, 15(2), 123-134.

Müller-Christ, G. (2001). Nachhaltiges Ressourcenmanagement. Marburg: Metropolis-Verlag.

Müller-Christ, G., \& Remer, A. (1999). Umweltwirtschaft oder Wirtschaftsökologie? Vorüberlegung zu einer Theorie des Ressourcenmanagements. In E. Seidel (ed.), Betriebliches Umweltmanagement im 21. Jabrbundert: Aspekte, Aufgaben, Perspektiven (pp. 69-87). Berlin: Springer.

Petkovic, M. (2007). Employer Branding. Ein markenpolitischer Ansatz. zur Schaffung von Präferenzen bei der Arbeitgeberwabl. München: Rainer Hampp Verlag.

Robinson, S.L. (1996). Trust and breach of the psychological contract. Administrative Science Quarterly, 41(4), 574-599. 
Rousseau, D.M. (1995). Psychological contracts in organizations. Understanding written and unwritten agreements. Thousand Oaks, CA: Sage Publications.

Rousseau, D.M. (2001). Schema, promise and mutuality: The building blocks of the psychological contract. Journal of Occupational and Organizational Psychology, 74(4), 511-541.

Schein, E.H. (1978). Career dynamics: Matching individual and organizational needs. Reading, MA: AddisonWesley Publishing Company.

Schuler, R.S., \& MacMillan, I.C. (1984). Gaining competitive advantage through human resource management practices. Human Resource Management, 23 3), 241-255.

SHRM. (2011). Advancing Sustainability: HR's role. A research report by the Society for Human Resource Management, BSR and Aurosoorya. Retrieved 24.04.2012, http://www.shrm.org/Research/SurveyFindings/Articles/Documents/110066 AdvSustainHR FNL FULL.pdf

Thom, N., \& Schüpbach-Brönnimann, C. (2003). Personalmanagement in Zeiten steter Veränderungen: Beständigkeit durch Nachhaltigkeit. In M. Becker, \& G. Rother (eds.), Personalwirtschaft in der Unternehmenstransformation. Stabilitas et Mutabilitas (pp. 91-109). München: Rainer Hampp.

Thom, N., \& Zaugg, R.J. (2004). Nachhaltiges und innovatives Personalmanagement. Spitzengruppenbefragung in europäischen Unternehmungen und Institutionen. In E.J. Schwarz (ed.), Nachbaltiges Innovationsmanagement (pp. 215-245). Wiesbaden: Gabler.

Trendence (2012). Deutschlands 100 Top-Arbeitgeber. Berlin: Trendence.

Turban, D.B. (2001). Organizational attractiveness as an employer on college campuses: An examination of the applicant population. Journal of Vocational Behavior, 58(2), 293-312.

Turban, D.B., \& Cable, D.M. (2003). Firm reputation and applicant pool characteristics. Journal of Organizational Behavior, 24(6), 733-751.

Turban, D.B., \& Greening, D.W. (1997). Corporate social performance and organizational attractiveness to prospective employees. Academy of Management Journal, 40(3), 658-672.

Wayne, S.J., Shore, L.M., \& Liden, R.C. (1997). Perceived organizational support and leader-member exchange: A social exchange perspective. Academy of Management Journal, 40(1), 82-111.

Wilkinson, A., Hill, M., \& Gollan, P. (2001). The sustainability debate. International Journal of Operations \& Production Management, 21(12), 1492-1502.

Wright, P.M., Dunford, B.B., \& Snell, S.A. (2001). Human resources and the resource based view of the firm. Journal of Management, 27(6), 701-721.

Wright, P.M., \& McMahan, G.C. (1992). Theoretical perspectives for strategic human resource management. Journal of Management, 18(2), 295-320.

Wright, P.M., McMahan, G.C., \& McWilliams, A. (1994). Human resources and sustained competitive advantage: A resource-based Perspective. International Journal of Human Resource Management, 5(2), 301 326.

Zaugg, R.J. (2009). Nachhaltiges Personalmanagement Eine neue Perspektive und empirische Exploration des Human Resource Management. Wiesbaden: Gabler.

Zaugg, R.J., Blum, A., \& Thom, N. (2001). Nachhaltiges Personalmanagement. Spitzengruppenbefragung in europäischen Unternehmungen und Institutionen. Bern: IOP-Verlag. 